\title{
Therapeutic value of octreotide for patients with severe dumping syndrome-a review of randomised controlled trials
}

\author{
J Li-Ling, M Irving
}

Approximately $10 \%-50 \%$ of patients develop some manifestations of the dumping syndrome after gastric surgery. Among them, 5\%-10\% have clinically significant symptoms, and $1 \%-2 \%$ are debilitated by them. ${ }^{1}$ Early dumping, typically starting 10-30 minutes after a meal, usually involves both vasomotor and gastrointestinal complaints such as sweating, palpitation, weakness and faintness, abdominal bloating, cramping, and profound diarrhoea. Late dumping, often occurring 2-3 hours postprandially, involves mainly vascular complaints characterised by perspiration, palpitation, mental confusion, and sometimes syncope. It is estimated that, among all affected patients, $75 \%$ have early dumping symptoms. The symptoms of early dumping probably result from rapid emptying of hyperosmolar chyme into the small bowel leading to a large fluid shift from the intravascular space into the intestinal lumen, with consequent rapid small bowel distension and an increase in both the amplitude and frequency of bowel contractions. Late dumping is a consequence of reactive hypoglycaemia resulting from an exaggerated insulin and glucagon-like peptide-1 release. ${ }^{2}$ The diagnosis of late dumping syndrome can be often confirmed through frequent blood sampling after a provocation test using $75 \mathrm{~g}$ of orally administrated glucose.

The management of the dumping syndrome can be achieved in most cases by dietary modification and adjustment of lifestyle, in particular reduction of carbohydrate intake. However, in approximately $3 \%-5 \%$ of patients, severe symptoms of dumping can continue despite dietary changes. This results in marked weight loss, fear of eating and outdoor activities, or even an inability to maintain full time employment. For the past decade it has been suggested that octreotide (Sandostatin SMS 210-995; Novartis Pharmaceuticals, East Hanover, NJ, USA), an analogue of somatostatin, can alleviate dumping by slowing gastric emptying, inhibiting insulin release, decreasing enteric peptide secretion, increasing intestinal absorption of water and sodium, slowing monosaccharide absorption, increasing gut transit time, and preventing haemodynamic changes. In particular, octreotide has been demonstrated to be effective in patients refractory to standard therapy. $^{34}$

Professor Sir Miles Irving,

Freeman Hospital, High

Heaton, Newcastle upon

Tyne NE7 7DN, UK

m.h.irving@ncl.ac.uk

Submitted 19 April 2000 Accepted 7 November 2000 symptoms of the dumping syndrome. Electronic databases (till end of March 2000) including Medline, EMBASE, and PubMed were searched using keywords including "randomis(z)ed trial", "dumping syndrome", and "octreotide". In addition, citations of relevant primary and review articles were examined.

\section{Result}

Seven randomised controlled trials (excluding one probably duplicated ${ }^{4}$ ) were identified..$^{5-11}$ The seven trials recruited a total of 63 patients with severe symptoms of dumping. Octreotide ( 50 or $100 \mu \mathrm{g}$ ) was given 15-60 minutes before either a meal or a provocative dose of oral glucose (75-100 g). The following evidence of the effectiveness of octreotide for ameliorating dumping symptoms after the provocative glucose challenge were extracted from the seven trials and are summarised in table 1 .

(1) Alleviating diarrhoea, abdominal pain, dizziness, and palpitation.

(2) Minimising changes in orthostatic pulse and blood pressure.

(3) Minimising influence on packed cell volume and plasma osmolarity.

(4) Preventing late hypoglycaemia by reducing peak insulin concentration and prolonging maximal plasma glucose concentration.

Compared with the control cases, octreotide pretreatment resulted in significant improvement in symptoms in nearly all patients. Decreased gain in pulse rates and stabilised blood pressure were particularly recorded in four trials. ${ }^{561011}$ Six trials described prevention of hypoglycaemia/rise of plasma insulin concentrations. ${ }^{56-11}$ One trial specifically recorded the induction of fasting migrating myoelectric complexes motility pattern (characteristic of interdigestive motility) and reduction in the duration and vigour of fed motility obtained with octreotide. ${ }^{7}$ However, the beneficial effect of octreotide on packed cell volume appeared uncertain. ${ }^{56-11}$ Furthermore, while two trials reported reduction of diarrhoea, ${ }^{58}$ three described development or worsening of this symptom. ${ }^{689}$

\section{Discussion}

A recent editorial in the British fournal of Surgery stressed the importance of systematic reviews in assessing the effectiveness of treatment. ${ }^{12}$ Systematic review aims to provide an unbiased summary of the evidence base to inform a clinical or policy question, to identify gaps in the research, and to improve the quality of new research. In the practice of "evidence 
Table 1 Randomised controlled trials on the effectiveness of octreotide for alleviating dumping syndrome after gastric/pancreatoduodenal surgery

\begin{tabular}{|c|c|c|c|c|}
\hline Studies & Design & Method & Impact of octreotide & Side effects \\
\hline $\begin{array}{l}\text { Hasler et al, } \\
\quad 1996^{5}\end{array}$ & $\begin{array}{l}\text { Double blind, placebo } \\
\text { controlled, crossover } \\
\text { with } 1 \text { week washout }\end{array}$ & $\begin{array}{l}\text { Eight patients with }>2 \text { year history } \\
\text { received octreotide } 50 \mu \mathrm{g} \text { or placebo } \\
45 \text { min before ingestion of } 75 \mathrm{~g} \\
\text { glucose; } 180 \text { min follow up }\end{array}$ & $\begin{array}{l}\text { Octreotide alleviated diarrhoea, dizziness, } \\
\text { and palpitation }(\mathrm{p}<0.001 \text { in all }), \text { minimised } \\
\text { pulse and blood pressure change }(\mathrm{p}<0.05), \\
\text { and prevented late hypoglycaemia }(\mathrm{p}<0.05) \text {. } \\
\text { It had no influence on packed cell volume or } \\
\text { plasma osmolarity }\end{array}$ & $\begin{array}{l}\text { Painful injection (worse with } \\
\text { placebo in four) }\end{array}$ \\
\hline Gray et al, $1991^{6}$ & $\begin{array}{l}\text { Double blind, placebo } \\
\text { controlled, crossover } \\
\text { with } 3 \text { days' washout }\end{array}$ & $\begin{array}{l}\text { Nine patients with severe dumping } \\
(4 \text { months to } 20 \text { years) received } \\
\text { octreotide } 100 \mu \mathrm{g} \text { or placebo } 30 \mathrm{~min} \\
\text { before ingestion of } 400 \mathrm{ml} \text { mix of } \\
40 \% \text { glucose, } 40 \% \text { fat and } 20 \% \\
\text { protein; } 180 \mathrm{~min} \text { follow up }\end{array}$ & $\begin{array}{l}\text { Octreotide alleviated clinical dumping } \\
(\mathrm{p}<0.05), \text { minimised pulse change }(\mathrm{p}<0.05), \\
\text { and prevented late hypoglycaemia in } 4 \\
\text { patients. It had no influence on packed cell } \\
\text { volume or plasma osmolarity }\end{array}$ & $\begin{array}{l}\text { Observed }^{\star} \text { during continual } \\
\text { octreotide treatment for an } \\
\text { average of } 5.7 \pm 1.3 \text { months }\end{array}$ \\
\hline $\begin{array}{l}\text { Richards et al, } \\
1990^{7}\end{array}$ & $\begin{array}{l}\text { Double blind, placebo } \\
\text { controlled, crossover in } \\
2 \text { consecutive days }\end{array}$ & $\begin{array}{l}\text { Six patients with severe early } \\
\text { dumping received octreotide } 100 \mu \mathrm{g} \\
\text { or placebo } 20 \text { min before ingestion } \\
\text { of a } 750 \text { calorie meal containing } 21 \mathrm{~g} \\
\text { protein, } 30 \mathrm{~g} \text { fat, and } 99 \mathrm{~g} \\
\text { carbohydrate; } 180 \text { min follow up }\end{array}$ & $\begin{array}{l}\text { Octreotide alleviated diarrhoea, abdominal } \\
\text { pain, palpitation, and nausea in all patients, } \\
\text { with shortened duration }(\mathrm{p}<0.03) \text { and } \\
\text { lowered vigour }(\mathrm{p}<0.03) \text { of postprandial } \\
\text { "fed" motility pattern }\end{array}$ & N/A \\
\hline Geer et al, $1990^{8}$ & $\begin{array}{l}\text { Double blind, placebo } \\
\text { controlled, crossover for } \\
2 \text { consecutive days }\end{array}$ & $\begin{array}{l}\text { Ten patients with severe dumping ( } 8 \\
\text { with early symptoms only) received } \\
100 \mu \mathrm{g} \text { octreotide or placebo } 30 \mathrm{~min} \\
\text { before ingestion of a } 750 \text { calorie } \\
\text { meal containing } 21 \mathrm{~g} \text { protein, } 30 \mathrm{~g} \\
\text { fat, and } 99 \mathrm{~g} \text { carbohydrate; } 180 \mathrm{~min} \\
\text { follow up }\end{array}$ & $\begin{array}{l}\text { Octreotide alleviated clinical dumping and } \\
\text { ablated diarrhoea }(\mathrm{p}<0.001) \text { and increase in } \\
\text { pulse or blood pressure, and prevented late } \\
\text { hypocalcaemia. It also delayed gastric } \\
\text { emptying. A } 15 \text { month treatment with } \\
\text { octreotide ( } 3-4 \text { doses daily) continued } \\
\text { diminution of symptoms and resulted in } \\
\text { weight gain in all patients, and enabled } 7 \\
\text { patients to return to work }\end{array}$ & $\begin{array}{l}\text { Mild transient abdominal cramp } \\
\text { in } 4.3 \text { on long term treatment } \\
\text { had diarrhoea relievable with } \\
\text { extra dose of octreotide }\end{array}$ \\
\hline $\begin{array}{l}\text { Tulassay et al, } \\
1989^{\circ}\end{array}$ & $\begin{array}{l}\text { Double blind, placebo } \\
\text { controlled, crossover for } \\
2 \text { consecutive days }\end{array}$ & $\begin{array}{l}\text { Eight patients with both early and } \\
\text { late dumping received } 50 \mu \mathrm{g} \text { or } \\
\text { placebo } 15 \mathrm{~min} \text { before ingestion of } \\
75 \mathrm{~g} \text { glucose; } 240 \text { min follow up }\end{array}$ & $\begin{array}{l}\text { Octreotide prevented the development of } \\
\text { both vasomotor and gastrointestinal } \\
\text { syndromes }(p<0.001) \text { and packed cell } \\
\text { volume changes. It also prevented } \\
\text { hypoglycaemia or rise in plasma insulin and } \\
\text { gastric inhibitory peptide concentrations } \\
(p<0.001)\end{array}$ & N/A \\
\hline $\begin{array}{l}\text { Primrose and } \\
\text { Johnston, } \\
1989^{410}\end{array}$ & $\begin{array}{l}\text { Randomised controlled } \\
\text { crossover trial for } 3 \\
\text { days }\end{array}$ & $\begin{array}{l}\text { Ten patients received placebo, } 50 \text { or } \\
100 \mu \text { octreotide } 60 \text { min before } \\
\text { ingestion of } 87.5 \mathrm{~g} \text { glucose; } 120 \mathrm{~min} \\
\text { follow up }\end{array}$ & $\begin{array}{l}\text { Octreotide alleviated symptoms in } 90 \% \text { of } \\
\text { cases }(50 \% \text { complete), and had a beneficial } \\
\text { effect }(\mathrm{p}<0.05) \text { on pulse, blood pressure, } \\
\text { packed cell volume, and blood glucose. } \\
\text { Three of } 4 \text { patients benefited from long term } \\
\text { treatment ( } 50 \mu \mathrm{g} 3 \text { times a day, up to } 4 \\
\text { years) }\end{array}$ & $\begin{array}{l}\text { For long treatment, } 2 \text { had severe } \\
\text { diarrhoea, } 1 \text { existing diarrhoea } \\
\text { was worsened }\end{array}$ \\
\hline$\underset{1988^{11}}{\operatorname{Hopman}}$ et al, & $\begin{array}{l}\text { Double blind, placebo } \\
\text { controlled, crossover } \\
\text { trial }\end{array}$ & $\begin{array}{l}\text { Twelve patients received placebo or } \\
\text { octreotide } 50 \mu \mathrm{g} 15 \mathrm{~min} \text { before } \\
\text { ingestion of } 50 \mathrm{~g} \text { glucose } / \mathrm{m}^{2} \text { body } \\
\text { surface; } 210 \mathrm{~min} \text { follow up }\end{array}$ & $\begin{array}{l}\text { Octreotide alleviated symptoms in all } \\
(\mathrm{p}<0.05) \text {, stabilised pulse rate }(\mathrm{p}<0.05) \\
\text { prevented hypoglycaemia }(\mathrm{p}<0.05), \text { but had } \\
\text { no effect on packed cell volume }\end{array}$ & None \\
\hline
\end{tabular}

*Two patients opted for surgery and had satisfactory outcome; four patients elected to stop octreotide, including two because of painful injection, one developed painful breast, and one had chest pain. Two patients required pancreatic enzyme replacement for steatorrhoea during octreotide treatment.

based medicine", systematic reviewing plays a crucial part by providing the key information.

Our identified studies, admittedly involving relatively small numbers of patients, have unanimously shown short term benefit as well as promising long term results, confirming octreotide as an effective treatment for dumping syndrome. Side effects of octreotide such as steatorrhoea or early morning diarrhoea associated with long term treatment were managed with pancreatic enzyme replacement or an extra dose of octreotide before bedtime. ${ }^{68}$ Notably, gallstone formation, as one of the most frequent side effects of octreotide therapy, was not observed among the identified trials. Based on their results, Geer et al suggested that, instead of gastrin or motilin, peptides such as pancreatic polypeptide, neurotensin, and glucagon may play a part in the development of dumping symptoms. ${ }^{8}$ Administration of octreotide 30 minutes before, or immediately after, a meal offers a practical and effective approach to the treatment of early and late dumping syndromes. We recommend that octreotide should be given for patients with severe or refractory dumping syndromes.
This review is supported by a grant to MI from the Leverhulme Trust.

1 Scarpignato C. The place of octreotide in the medical management of the dumping syndrome. Digestion 1996;57(suppl 1):114-8.

2 Vecht J, Masclee AA, Lamers CB. The dumping syndrome. Current insights into pathophysiology, diagnosis and treatment. Scand f Gastroenterol 1997;223(suppl):21-7.

3 O'Donnell LJ, Farthing MJ. Therapeutic potential of a long acting somatostatin analogue in gastrointestinal diseases. Gut 1989;30:1165-72.

4 Primrose JN. Octreotide in the treatment of the dumping syndrome. Digestion 1990;45(suppl 1):49-58.

5 Hasler WL, Soudah HC, Owyang C. Mechanisms by which Hasler WL, Soudah HC, Owyang C. Mechanisms by which
octreotide ameliorates symptoms in the dumping syndrome. octreotide ameliorates symptoms in the du

F Pharmacol Exp Ther 1996;277:1359-65.
6 Gray JL, Debas HT, Mulvihill SJ. Control of dumping Gray JL, Debas HT, Mulvihill SJ. Control of dumping

7 Rurgery. Arch Surg 1991;126:1231-5. Richards WO, Geer R, O'Dorisio TM, et al. Octreotide
acetate induces fasting small bowel motility in patients with dumping syndrome. $\mathcal{F}$ Surg Res 1990;49:483-7.

8 Geer RJ, Richards WO, O'Dorisio TM, et al. Efficacy of octreotide acetate in treatment of severe postgastrectomy dumping syndrome. Ann Surg 1990;212:678-87.

9 Tulassay Z, Tulassay T, Gupta R, et al. Long acting somatostatin analogue in dumping syndrome. Br F Surg 1989;76: 1294-5.

10 Primrose JN, Johnston D. Somatostatin analogue SMS 201-995 (octreotide) as a possible solution to the dumping syndrome after gastrectomy or vagotomy. $\mathrm{Br} \quad \mathcal{F}$ Surg 1989;76:140-4.

11 Hopman WP, Wolberink RG, Lamers CB, et al. Treatment of the dumping syndrome with the somatostatin analogue SMS 201-995. Ann Surg 1988;207:155-9.

12 Sheldon TA. Systematic reviews and meta-analyses: the value for surgery. Br F Surg 1999;86:977-8. 